\title{
EHMTI-0356. Hypnic headache in a patient with sunct: case report
}

\author{
A Granato*, J Fantini, N Koscica \\ From 4th European Headache and Migraine Trust International Congress: EHMTIC 2014 \\ Copenhagen, Denmark. 18-21 September 2014
}

\section{Case description}

A 49 year-old healthy woman developed two rare primary headaches.

At the age of 23 she experienced single painful stabs in the left orbital-temporal region lasting few seconds, every 6-7 months. In the subsequent 3 years the single pain attacks became longer in duration, they were accompanied by ipsilateral conjunctival injection and tearing, and frequency increased to 20 episodes/day for 5-10 consecutive days, with pain free intervals of 6-7 months. Brain MRI ruled out secondary headaches. In the following years, active periods reached the duration of 3 consecutive months, with remissions of 1 month. Six years ago, the patient was evaluated in our Headache Centre, a SUNCT (short-lasting unilateral headache with conjunctival injection and tearing) was diagnosed, and lamotrigine $100 \mathrm{mg} /$ day was effectively administered. The pain recurred after therapy discontinuation, so she was forced to continue lamotrigine.

She was pain-free for further 2 years, then she began suffering from a new occipital bilateral pressing pain, moderate, sometimes with nausea, presenting exclusively during sleep and causing awakening. Attacks occurred usually at 4:00-5.30 a.m., lasted about 60 minutes and gradually became near daily. A diagnosis of hypnic headache was made and the patient was treated with caffeine 30 minutes before sleeping, without headache recurrence.

\section{Conclusions}

At the best of our knowledge, this is the first description of SUNCT and hypnic headache occurring in the same patient. The pathogenetic mechanisms of this coexistence are interesting. In this patient the combined specific treatment of both SUNCT and hypnic headache was effective.

\footnotetext{
Neurologic Clinic Headache Centre University of Trieste, Department of Medical Surgical and Health Sciences, Trieste, Italy
}

No conflict of interest.

Published: 18 September 2014

doi:10.1186/1129-2377-15-S1-J6

Cite this article as: Granato et al:: EHMTI-0356. Hypnic headache in a patient with sunct: case report. The Journal of Headache and Pain 2014 15(Suppl 1):J6.

\section{SpringerOpen ${ }^{\odot}$}

(C) 2014 Granato et al; licensee Springer. This is an Open Access article distributed under the terms of the Creative Commons Attribution License (http://creativecommons.org/licenses/by/2.0), which permits unrestricted use, distribution, and reproduction in any medium, provided the original work is properly cited.
Submit your manuscript to a SpringerOpen ${ }^{\circ}$ journal and benefit from:

- Convenient online submission

- Rigorous peer review

- Immediate publication on acceptance

- Open access: articles freely available online

- High visibility within the field

Retaining the copyright to your article

Submit your next manuscript at $>$ springeropen.com 